\title{
Efektivitas Profilaksis Primer Filgrastim Pada Pasien Kanker Payudara terhadap Insiden Neutropenia
}

\author{
Andri Utomo', ${ }^{1}$ Widyati $^{2}$, Arif Supono ${ }^{2}$ dan Dwi Hari Susilo ${ }^{3}$ \\ ${ }^{1}$ Program Studi Magister IImu Farmasi, Fakultas Farmasi, Universitas Surabaya, Indonesia \\ ${ }^{2}$ RSPAL Dr. Ramelan Surabaya, Surabaya, Indonesia \\ ${ }^{3}$ Rumah Sakit Onkologi, Surabaya, Indonesia \\ Korespondensi: Andri Utomo \\ Email: andriutomo04@gmail.com
}

Submitted : 29-03-2020, Revised : 14-04-2020, Accepted : 20-05-2020

\begin{abstract}
ABSTRAK : Kejadian febrile neutropenia menyebabkan penundaan jadwal kemoterapi, penurunan dosis kemoterapi, bahkan dapat menghentikan proses kemoterapi yang harus dijalani. Hal ini dapat berakibat pada penurunan tingkat keberhasilan terapi pada pasien kanker payudara. Kejadian neutropenia dapat dicegah dengan pemberian profilaksis primer granulocyte colony-stimulating factor (G-CSF), seperti filgrastim. Pemberian filgrastim dapat mengurangi risiko terjadinya febrile neutropenia, perawatan di Rumah Sakit, dan kematian pada pasien kanker payudara. Oleh karena itu, penelitian ini dilakukan untuk menganalisis efektivitas pemberian profilaksis filgrastim primer pada pasien kanker payudara yang mendapat kemoterapi. Penelitian ini merupakan jenis penelitian observasional analitik dengan rancang bangun prospective cohort study. Sampel yang digunakan yaitu 87 pasien kanker payudara yang sedang menjalani kemoterapi. Variabel yang diteliti adalah insiden neutropenia dan faktor risiko yang menyebabkan neutropenia. Hasil penelitian menunjukkan bahwa faktor risiko yang berpengaruh secara langsung terhadap insiden neutropenia adalah usia $(p=0,000)$, luas permukaan tubuh $(\mathrm{p}=0,037)$, jenis kemoterapi $(\mathrm{p}=0,000)$, siklus kemoterapi $(\mathrm{p}=0,000)$, dan regimen kemoterapi $(p=0,000)$. Adanya profilaksis filgrastim primer efektif dalam menurunkan insiden neutropenia.
\end{abstract}

Kata kunci: profilaksis primer filgrastim; neutropenia; kanker payudara; kemoterapi

ABSTRACT: Neutropenia caused delaying chemotherapy schedule, decreasing chemotherapy dose, and even stopping chemotherapy treatment. These might affect the patient's outcome rate. Neutropenia can be prevented by giving primary prophylaxis granulocyte colony-stimulating factor ( $G$-CSF), such as filgrastim. Filgrastim can reduce the risk of febrile neutropenia, hospitalization, and death rate in breast cancer patients. Therefore, this study was conducted to analyze the effectiveness of primary filgrastim prophylaxis in breast cancer patients who receiving chemotherapy. This research was an analytic observational study with a prospective cohort design. The samples used were 87 breast cancer patients who were undergoing chemotherapy. The variables of this study were risk factors that cause neutropenia and neutropenia incidents. The results showed that the risk factors that directly affected neutropenia incidents are age $(p=0.000)$, body surface area $(p=0.037)$, type of chemotherapy $(p=0.000)$, chemotherapy cycle $(p=0.000)$, and chemotherapy regiment $(p=0.000)$. Primary filgrastim prophylaxis is effective on reducing neutropenia incidents based on indirect effect of risk factors to neutropenia incidents ( $p=0.001)$ and direct effect of primary filgrastim prophylaxis to neutropenia incidents $(p=0.000)$.

Keywords: filgrastim primary prophylaxis; neutropenia incidents; breast cancer; chemotherapy 


\section{Pendahuluan}

Penyakit kanker merupakan salah satu penyebab kematian utama di seluruh dunia. Kematian akibat kanker di tahun 2012 sebesar 8,2 juta orang dimana 2,9 juta terjadi pada negara-negara maju dan 5,3 juta kematian pada negara-negara berkembang. Pada 2030 diprediksi kejadian kasus baru kanker sebesar 21,7 juta dan 13 juta kematian akibat kanker [1].

Secara global diketahui kanker yang paling sering terjadi pada wanita adalah kanker payudara, karena terdapat sekitar 2,1 juta wanita setiap tahun yang terdiagnosis kanker payudara. Selain itu, kanker payudara juga menjadi penyebab kematian terbesar akibat kanker pada wanita. Pada tahun 2019 terdapat sekitar 41.760 wanita meninggal akibat kanker payudara [1].

Dalam rangka mengontrol angka kematian akibat kanker payudara pada wanita, diperlukan penanganan yang komperhensif mulai dari petunjuk untuk skrining secara rutin, diagnosis sedini mungkin, hingga modalitas terapi kanker payudara yang sesuai dengan prosedur [1]. Salah satu modalitas terapi kanker payudara yang dapat dipilih pada stadium I, II, III, dan IV adalah kemoterapi [2]. Kemoterapi dapat bekerja dengan cara membunuh sel kanker melalui perusakan Deoxyribose-Nucleic Acid (DNA), mengganggu sintesis DNA, atau menghambat pembelahan dari sel kanker tersebut.

Kemoterapi memiliki berbagai efek samping, yaitu rambut rontok, mual dan muntah, nyeri neuropati, konstipasi dan diare, serta kelainan hematologi. Efek samping yang sering terjadi adalah gangguan hematologi dan neutropenia merupakan kelainan hematologi yang sering terjadi (sekitar 90\%) pada pasien yang diberikan kemoterapi $[3,4]$. Kondisi neutropenia dapat terjadi 7-10 hari setelah kemoterapi dan terdapat komplikasi neutropenia yang berbahaya yaitu febrile neutropenia [5-7]. Febrile neutropenia didefinisikan sebagai suatu kondisi dengan nilai absolute neutrophil count (ANC) $<1000 / \mu \mathrm{L}$ dan suhu $>38^{\circ} \mathrm{C}[8,9]$.
Penderita kanker payudara yang mendapat kemoterapi berisiko mengalami febrile neutropenia sebesar 20,6\%, berpotensi dirawat di Rumah Sakit sebesar 94\%, dan memiliki risiko mengalami kematian sebesar $10,3 \%$, serta membutuhkan biaya perawatan sebesar $\$ 16,291$ - $\$ 19,456$ $[10,11]$. Selain itu, febrile neutropenia merupakan penanda terjadinya infeksi yang memiliki risiko terjadi sepsis sebesar $>50 \%$. Selain itu pada pasien yang mengalami febrile neutropenia berisiko mengalami perawatan di Rumah Sakit dan mendapat terapi antibiotik intravena [12].

Keadaan febrile neutropenia dapat dicegah dengan pemberian profilaksis primer Granulocyte colony-stimulating factor (G-CSF), seperti filgrastim [12]. Pemberian filgrastim dapat mengurangi risiko terjadinya febrile neutropenia, perawatan di Rumah Sakit, dan kematian pada 2.156 pasien kanker payudara. Pada pasien lansia dengan solid tumor yang diberikan filgrastim, risiko kejadian perawatan karena febrile neutropenia di Rumah Sakit menurun dari 9\% menjadi $5 \%$ [7]. Oleh karena itu, penelitian ini dilakukan untuk menganalisis efektivitas pemberian profilaksis primer filgrastim pada pasien kanker payudara yang mendapat kemoterapi.

\section{Metode}

\subsection{Jenis penelitian}

Penelitian ini merupakan jenis penelitian observasional analitik dengan rancang bangun penelitian prospective cohort study. Penelitian dilakukan di RS X Surabaya selama tiga bulan yaitu pada bulan Mei hingga Agustus 2019.

\subsection{Subyek}

Subyek penelitian adalah pasien kanker payudara yang menjalani kemoterapi di RS X Surabaya. Sampel penelitian yang diambil telah memenuhi kriteria inklusi dan eksklusi. Kriteria inklusi dalam pengambilan sampel penelitian ini adalah pasien yang berusia 18-60 tahun dan menjalani perawatan kemoterapi dengan diagnosis kanker payudara stadium I, II, dan III; pasien yang menjalani kemoterapi adjuvant dan 
neo-adjuvant. Sedangkan kriteria eksklusinya adalah pasien yang menjalani radiasi, dan mendapat obat monoklonal antibodi, serta menjalani kemoterapi lebih dari 1 hari.

Cara pengambilan sampel penelitian ini menggunakan metode probability sampling (simple random sampling). Berdasarkan perhitungan pengambilan sampel, diketahui bahwa besar sampel minimal yang harus diambil adalah 84 orang. Pada penelitian ini, partisipan yang bersedia mengikuti penelitian yaitu sebanyak 90 orang, tetapi terdapat 3 orang drop out sehingga total partisipan adalah 87 orang. Tiga orang yang drop out dikarenakan partisipan mendapat perubahan terapi dan partisipan melakukan kemoterapi di Rumah Sakit lain.

\subsection{Prosedur}

Penelitian ini telah mendapatkan izin dari manajemen RS XSurabaya dan dilaksanakan pada bulan Mei-Agustus 2019 setelah mendapatkan ethical clearance dari komite etik RSAL dr. Ramelan (sertifikat kelaikan etik nomor: 93/ EC/KERS/2019). Partisipan yang setuju untuk ikut penelitian ini diminta untuk mengisi dan menandatangani lembar persetujuan (informed consent), selanjutnya data pasien diambil pada rekam medis dan dilakukan wawancara untuk memperoleh informasi yang tidak terdapat pada rekam medis seperti, tinggi badan pasien, penyakit penyerta, dan apakah partisipan sedang melakukan radiasi. Data rekam medis yang dicatat adalah jadwal kemoterapi, data demografi, data klinik, dan data laboratorium.

Data yang telah dikumpulkan kemudian dianalisis menggunakan analisis univariat untuk mengetahui distribusi frekuensi pada karakteristik demografi partisipan. Selain itu, juga dilakukan analisis jalur untuk mengetahui pengaruh efektivitas filgrastim pada insiden neutropenia.

\subsection{Variabel penelitian}

Variabel yang diteliti meliputi variabel bebas, variabel antara, dan variabel terikat. Variabel bebas dalam penelitian ini yaitu usia, jenis kelamin, luas permukaan tubuh (LPT), penyakit penyerta, jenis kemoterapi, stadium kanker, regimen kemoterapi, siklus kemoterapi. Variabel antara yaitu profilaksis filgrastim primer, dan variabel terikatnya adalah insiden neutropenia.

\section{Hasil dan pembahasan}

\subsection{Karakteristik demografi}

Data diambil dari 87 orang partisipan dengan rata-rata usia pasien 56-65 tahun sebanyak $49,41 \%$ dan $100 \%$ pasien berjenis kelamin perempuan. Luas permukaan tubuh (LPT) pasien terbanyak adalah LPT 1,3-1,5 sebesar 54,02\% dan sebagian besar pasien tidak ada penyakit penyerta (91,95\%). Jenis kemoterapi pada pasien terbanyak adalah neo adjuvant $(96,55 \%)$ dan stadium kanker payudara paling banyak adalah IIIA-IIIC (60,92\%). Sedangkan regimen kemoterapi yang diketahui sering digunakan adalah kombinasi docetaxel, epirubisin, dan cyclofosfamid sebanyak 32,18\%. Data karakteristik demografis selain siklus kemoterapi terdapat pada Tabel 1.

Pada penelitian ini, setiap pasien diamati selama 3 siklus. Sehingga data siklus kemoterapi berjumlah tiga kali jumlah pasien partisipan penelitian, yaitu sebanyak 261. Berdasarkan hasil penelitian diketahui bahwa paling banyak pasien masuk dalam siklus 3-4 yaitu sebanyak 65,13\% (Tabel 2).

Karakteristik demografi pasien yang telah ditampilkan pada Tabel 1 dan 2 merupakan faktor risiko dari insiden neutropenia. Sehingga keseluruhan karakteristik demografi pasien sebagai faktor risiko dicari hubungan dan pengaruhnya terhadap insiden neutropenia, kecuali jenis kelamin karena tidak ada varian jenis kelamin pada penelitian ini (hanya perempuan), sehingga tidak bisa dilakukan analisis hubungan dan pengaruh terhadap insiden neutropenia.

\subsection{Profilaksis filgrastim primer}

Dalam rangka mengontrol proliferasi dari sel 
Tabel 1. Karakteristik demografi responden

\begin{tabular}{|c|c|c|c|c|}
\hline No. & Parameter & Klasifikasi & $\mathbf{n}$ & $\%$ \\
\hline \multirow[t]{4}{*}{1.} & Usia (tahun) & $36-45$ & 8 & 9,19 \\
\hline & & $46-55$ & 36 & 41,40 \\
\hline & & $56-65$ & 43 & 49,41 \\
\hline & & $>65$ & 0 & 0 \\
\hline \multirow[t]{2}{*}{2.} & Jenis Kelamin & Pria & 0 & 0 \\
\hline & & Wanita & 87 & 100 \\
\hline \multirow[t]{2}{*}{3.} & LPT & $1,3-1,5 \mathrm{~m}^{2}$ & 47 & 54,02 \\
\hline & & $1,6-1,8 \mathrm{~m}^{2}$ & 40 & 45,98 \\
\hline \multirow[t]{6}{*}{4.} & Penyakit penyerta & Tidak ada & 76 & 87,36 \\
\hline & & HT & 6 & 6,90 \\
\hline & & $\mathrm{DM}$ & 4 & 4,60 \\
\hline & & $\mathrm{HT}+\mathrm{DM}$ & 1 & 1,14 \\
\hline & & Hipertiroid & 0 & 0 \\
\hline & & Hipertiroid + DM + HT & 0 & 0 \\
\hline \multirow[t]{2}{*}{5.} & Jenis kemoterapi & Neo-Adjuvant & 84 & 96,55 \\
\hline & & Adjuvant & 3 & 3,45 \\
\hline \multirow[t]{2}{*}{6.} & Stadium kanker payudara & IIA-IIB & 34 & 39,08 \\
\hline & & IIIA-IIIC & 53 & 60,92 \\
\hline \multirow[t]{6}{*}{7.} & Regimen kemoterapi & Docetaxel, epirubisin, dan cyclofosfamid & 28 & 32,18 \\
\hline & & Cyclofosfamid dan epirubisin & 20 & 22,99 \\
\hline & & Cyclofosfamid dan docetaxel & 17 & 19,54 \\
\hline & & Docetaxel dan epirubisin & 6 & 6,90 \\
\hline & & Paclitaxel dan carboplatin & 16 & 18,39 \\
\hline & & Paclitaxel dan cyclofosfamid & 0 & 0 \\
\hline
\end{tabular}

LPT: luas permukaan tubuh; HT: hipertensi; DM: diabetes mellitus

Tabel 2. Karakteristik regimen kemoterapi

\begin{tabular}{llll}
\hline No. & Siklus kemoterapi & $\mathbf{n}$ & $\mathbf{\%}$ \\
\hline 1. & $1-2$ & 45 & 17,24 \\
2. & $3-4$ & 170 & 65,13 \\
3. & $5-6$ & 46 & 17,63 \\
\multicolumn{2}{l}{ Total } & 261 & 100,00 \\
\hline
\end{tabular}

Keterangan: $\mathrm{n}=1$ pasien diamati selama 3 siklus

progenitor, memicu pematangan sel neutrofil, serta menstimulasi pelepasan neutrofil dari sumsum tulang belakang, pada penelitian ini dilakukan analisis profilaksis filgrastim yang termasuk ke dalam golongan granulocyte colony stimulating factor (G-CSF).

Granulocyte colony stimulating factor (G-CSF) adalah suatu glikoprotein yang memiliki kemam- puan atau dapat memfasilitasi pembentukan/ pematangan neutrofil dari sumsum tulang belakang. G-CSF diproduksi tubuh dalam jumlah besar jika terstimulasi oleh infeksi dan kerusakan jaringan. Beberapa sel dapat memproduksi G-CSF apabila terinduksi oleh makrofag yang berada di endothelium [13]. Filgrastim adalah asam amino nomor 175 yang diproduksi dari teknologi DNA 
rekombinan. Produksi filgrastim berasal dari bakteri Escherichia coli yang dimasukkan ke dalam gen G-CSF manusia [14]. Pemilihan filgrastim dikarenakan pertimbangan harga dari filgrastim lebih murah dibandingkan jenis G-CSF yang lain [7].

\subsection{Analisis faktor risiko}

Berdasarkan hasil penelitian (Gambar 1) diketahui bahwa faktor risiko pasien yang terdiri dari usia, LPT, penyakit penyerta, stadium kanker, jenis kemoterapi, siklus kemoterapi, regimen kemoterapi memiliki pengaruh yang bermakna secara tidak langsung oleh adanya profilaksis filgrastim primer $(p=0,001)$. Begitu pula pengaruh yang terjadi antara filgrastim primer terhadap neutropenia yang memiliki pengaruh langsung secara bermakna ( $p=0,000)$ (Tabel 3 ). Hal ini menunjukkan bahwa pada pasien dengan faktor risiko neutropenia, dengan adanya intervensi profilaksis filgrastim primer, secara tidak langsung dapat menurunkan insiden neutropenia pada pasien.

Adapun faktor risiko yang berpengaruh secara langsung terhadap insiden neutropenia diantaranya adalah usia $(\mathrm{p}=0,000)$, LPT $(\mathrm{p}=0,037)$, jenis kemoterapi $(p=0,000)$, siklus kemoterapi $(p=0,000)$, dan regimen kemoterapi $(p=0,000)$. Sedangkan faktor risiko penyakit penyerta dan stadium kanker tidak berpengaruh terhadap kejadian neutropenia karena memiliki nilai $\mathrm{p}>0,05$ (Tabel 4).

Pada penelitian ini 3 pasien yang mengalami febrile neutropenia (FN) berusia lebih dari 65 tahun dan menurut Smith et al. (2015) terdapat hubungan antara usia dengan kejadian FN, pada usia $\geq 65$ tahun meningkatkan risiko terjadinya FN dikarenakan adanya perubahan fungsi fisiologis pada pasien yang memiliki solid tumor atau lyphoma non hodgkin [7,15]. Penggunaan profilaksis G-CSF pada pasien dengan usia >65 tahun yang menderita solid tumor dapat menurunkan perawatan di rumah sakit akibat FN dari 9\% menjadi 5\% [16].

Sebuah penelitian double-blinded membandingkan pemberian filgrastim dengan plasebo terhadap insiden FN pada pasien kanker paru menunjukkan hasil bahwa jenis kelamin wanita

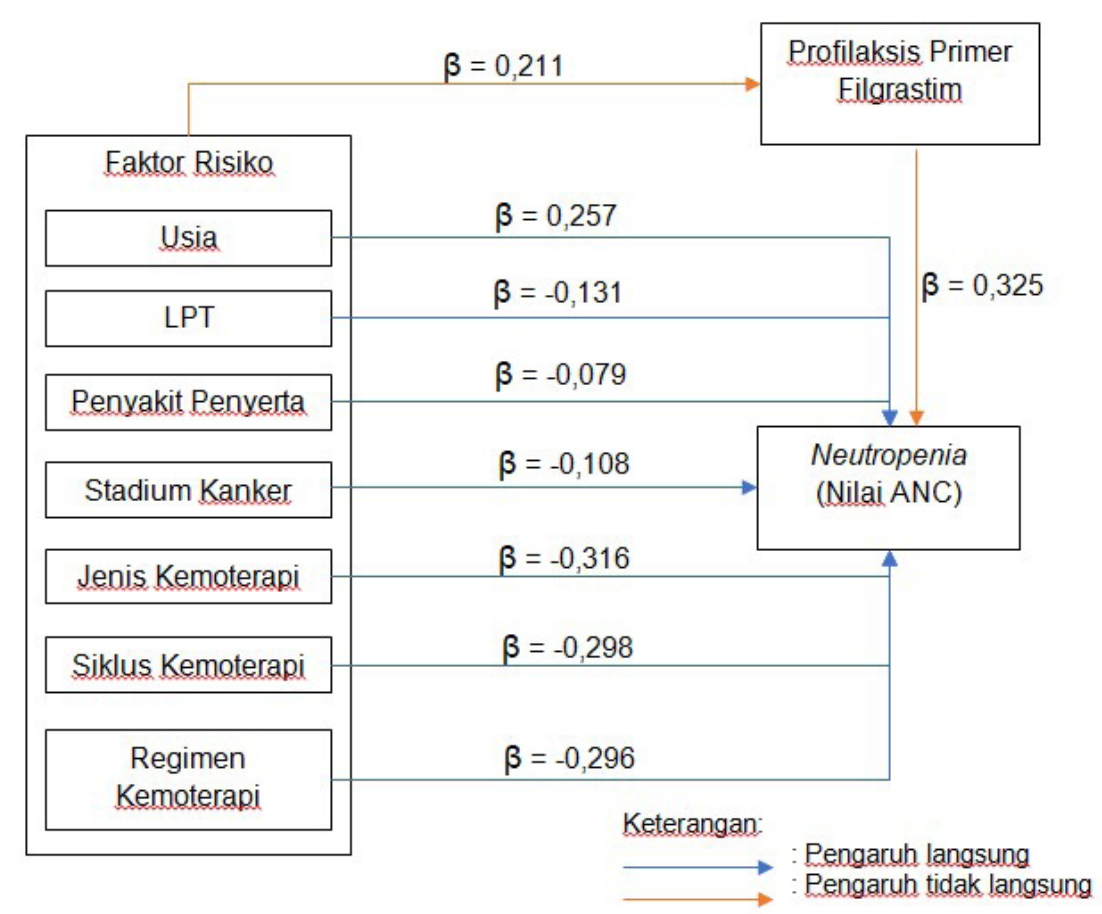

Gambar 1. Analisis jalur efektivitas profilaksis primer filgrastim pada pasien kanker payudara terhadap insiden neutropenia 
Tabel 3. Karakteristik regimen kemoterapi

\begin{tabular}{lllll}
\hline No & Variabel independent & Variabel dependent & Nilai $\mathbf{p}$ & Nilai $\boldsymbol{\beta}$ \\
\hline 1. & Faktor risiko & Filgrastim primer & 0,001 & 0,211 \\
2. & Filgrastim primer & Nilai ANC & 0,000 & 0,325 \\
\hline
\end{tabular}

Keterangan: Nilai $p$ bermakna apabila $<0,05$

Tabel 4. Analisis pengaruh langsung

\begin{tabular}{lllll}
\hline No & Variabel independent & Variabel dependent & Nilai $\mathbf{p}$ & Nilai $\boldsymbol{\beta}$ \\
\hline 1 & Usia & Nilai ANC & 0,000 & 0,257 \\
2 & LPT & Nilai ANC & 0,037 & $-0,131$ \\
3 & Penyakit penyerta & Nilai ANC & 0,615 & $-0,079$ \\
4 & Stadium kanker & Nilai ANC & 0,329 & $-0,108$ \\
\hline 5 & Jenis kemoterapi & Nilai ANC & 0,000 & $-0,316$ \\
6 & Siklus kemoterapi & Nilai ANC & 0,000 & $-0,298$ \\
7 & Regimen kemoterapi & Nilai ANC & 0,000 & $-0,269$ \\
\hline
\end{tabular}

ANC: Absolute Neutrophil Count, Nilai p bermakna apabila $<0,05$

lebih berisiko mengalami FN dibandingkan pria [17]. Menurut Scott et al. (2003) menyatakan bahwa jenis kelamin wanita memiliki odds ratio 1,878 mengalami FN walaupun sudah mendapat profilaksis primer filgrastim [18].

Karakteristik LPT dalam penelitian ini didapatkan hasil 1,3-1,8 m². Pada populasi Asia tidak ada standard untuk LPT, tetapi rerata LPT populasi USA $\left(1,86 \mathrm{~m}^{2}\right)$, Australia $\left(1,80 \mathrm{~m}^{2}\right)$, dan UK $(1,79$ $\mathrm{m}^{2}$ ) [19]. Nilai LPT $<1,47 \mathrm{~m}^{2}$ berisiko mengalami FN dan jika terjadi FN berisiko mengalami perawatan di rumah sakit [19-21]. LPT yang rendah berhubungan dengan rendahnya asupan gizi dan nutrisi penderita, pada pasien yang mendapat kemoterapi dianjurkan untuk mengatur pola makan seperti asupan protein yang tinggi untuk meningkatkan produksi sel darah putih dan menjaga berat tubuh ideal [8]. Selain LPT, indeks massa tubuh (IMT) yang rendah juga memiliki risiko mengalami FN dengan OR 4,4 [19].

Menurut Lyman et al. (2014) adanya penyakit penyerta pada kanker merupakan hal yang sangat signifikan meningkatkan risiko untuk mengalami FN atau dirawatnya di rumah sakit karena FN [8]. Adanya gangguan ginjal semakin meningkatkan risiko terjadinya FN, hal ini dapat terjadi dikare- nakan menurunnya produksi sel darah putih dari sumsum tulang belakang akibat adanya inflamasi atau malnutrisi $[22,23]$. Sebuah penelitian yang dilakukan Hosmer et al. (2011) pada pasien kanker payudara, paru, prostat, dan kolorektal menyatakan bahwa semakin banyak jumlah penyakit penyerta berkorelasi dengan semakin tingginya risiko mengalami FN. Satu penyakit penyerta $(\mathrm{OR}=1,13) ; 2$ penyakit penyerta $(\mathrm{OR}=$ 1,39); dan 3 penyakit penyerta $(\mathrm{OR}=1,81)$ [24]. Pada penelitian ini, 3 responden yang mengalami FN; 2 orang memiliki 1 penyakit penyerta dan 1 orang memiliki 2 penyakit penyerta.

Obat-obat kemoterapi dapat menyebabkan terjadinya neutropenia dengan tingkat myelosupresi yang bervariasi; golongan antrasiklin (epirubisin dan doxorubisin), taxan (docetaxel dan paclitaxel), alkylators (cyclofosfamid), topoisomerase inhibitors (etoposide), gemsitabin, dan vinorelbine adalah obat-obatan dengan myelosupresi yang tinggi. Kemoterapi pada kanker payudara memiliki regimen yang bervariasi dan kombinasi 3 obat kemoterapi dapat meningkatkan risiko terjadinya FN [8]. Pada penelitian ini regimen kemoterapi tertinggi yang digunakan adalah kombinasi docetaxel, epirubisin, dan 
cyclofosfamid. Pasien kanker payudara yang mendapat kemoterapi kombinasi antrasiklin/ taxan dan docetaxel memiliki risiko mengalami FN sebesar $>20 \%$; selain itu, gologan taxan pada ras Asia menimbulkan toksisitas yang lebih besar dibanding ras Kaukasian. Penelitian yang dilakukan di Korea pada pasien kanker payudara untuk melihat insiden FN dengan kemoterapi docetaxel, epirubisin, dan cyclofosfamid selama 6 siklus tanpa pemberian profilaksis primer G-CSF menunjukkan hasil 63,4\% terjadi insiden FN [25].

Pada penelitian ini terjadi 3 insiden febrile neutropenia dari 87 responden (3,45\%). Sebuah meta analisis dengan 59 RCTs, perbandingan pemberian profilaksis primer dengan tanpa profilaksis G-CSF pada pasien solid tumor atau lymphoma menunjukkan hasil menurunnya angka kematian karena pemberian profilaksis primer filgrastim (RR = 0,93) [7]. Pemberian profilaksis primer G-CSF menurunkan angka kematian akibat infeksi sebesar 1,5\% dibanding tanpa profilaksis primer 2,8\% [26].

Keterbatasan dalam penelitian ini adalah pengamatan hanya dilakukan 3 siklus kemoterapi dan setiap siklus kemoterapi tidak sama dikarenakan terbatasnya waktu penelitian. Penelitian yang dilakukan Lyman et al. (2014) dilakukan selama 6 siklus dengan siklus yang sama [8].

\section{Kesimpulan}

Usia, luas permukaan tubuh, jenis kemoterapi, siklus kemoterapi dan regimen kemoterapi merupakan faktor risiko yang berpengaruh secara langsung terhadap terjadinya neutropenia. Adanya profilaksis filgrastim primer efektif dalam menurunkan insiden neutropenia berdasarkan pengaruh tidak langsung dari faktor risiko terhadap insiden neutropenia ( $p=0,001$ ) dan pengaruh langsung profilaksis filgrastim primer terhadap insiden neutropenia $(\mathrm{p}=0,000)$.
1. Chopra S, Davies EL. Breast Cancer. Medicine. 2020;48(2):113-8.

2. Nounou M, ElAmrawy F, Helal N, Abdelraouf K, Goda S, Syed-Sha-Qhattal H. Breast Cancer: Conventional Diagnosis and Treatment Modalities and Recent Patents and Technologies. Breast Cancer Basic Clinical Research. 2015;9(S2):17-34.

3. Othieno-Abinya NA, Waweru A, Nyabola LO. Chemotherapy Induced Myelosuppression. East Afr Med J. 2007;84(1):8-15.

4. Abernethy AP, Barbour SY, Uronis H, Zafar SY, Coan A, Rowe K, et al. Quality management of potential chemotherapy-induced neutropenic complications: Evaluation of practice in an academic medical center. Support Care Cancer. 2009;17(6):735-44.

5. Cameron D. Management of chemotherapyassociated febrile neutropenia. $\mathrm{Br} J$ Cancer. 2009;101(S1):S18-22.

6. Åvall Lundqvist E, Fujiwara K, Seoud M. Principles of chemotherapy. Int $J$ of Gynecol Obstet. 2015;131:S146-9.

7. Smith TJ, Bohlke K, Lyman GH, Carson KR, Crawford J, Cross SJ, et al. Recommendations for the use of WBC growth factors: American society of clinical oncology clinical practice guideline update. J Clin Oncol. 2015;33(28):3199-212.

8. Lyman GH, Abella E, Pettengell R. Risk factors for febrile neutropenia among patients with cancer receiving chemotherapy: A systematic review. Crit Rev Oncol Hematol. 2014;90(3):1-10.

9. Kuderer NM, Dale DC, Crawford J, Cosler LE, Lyman GH, Jamal L. Mortality, Morbidity, and Cost Associated with Febrile Neutropenia in Adult Cancer Patients. Am Soc Clin Oncol. 2006;106(10):2258-66.

10. Tai E, Guy GP, Dunbar A, Richardson LC. Cost of Cancer-Related Neutropenia or Fever Hospitalizations. J Oncol Pract. 2017;13(6):e55261.

11. Weycker D, Barron R, Kartashov A, Legg J, Lyman $\mathrm{GH}$. Incidence, treatment, and consequences of chemotherapy-induced febrile neutropenia in the inpatient and outpatient settings. J Oncol Pharm Pract. 2014;20(3):190-8.

\section{Daftar Pustaka}

Media Pharmaceutica Indonesiana Vol. 3 No. 1 June 2020 
12. Penack O, Becker C, Buchheidt D, Christopeit M, Kiehl M, Von Lilienfeld-Toal M, et al. Management of sepsis in neutropenic patients: 2014 Updated guidelines from the Infectious Diseases Working Party of the German Society of Hematology and Medical Oncology (AGIHO). Ann Hematol. 2014;93(7):1083-95.

13. Wright CR, Ward AC, Russell AP. Granulocyte Colony-Stimulating Factor and Its Potential Application for Skeletal Muscle Repair and Regeneration. Mediators Inflamm. 2017;1-10.

14. Wells BG, Dipiro JT, Schwinghammer TL, Dipiro C V. Pharmacotherapy Handbook. Ninth Edit. New York: McGraw-Hill; 2015.

15. Lee J, Lee JE, Kim Z, Han SW, Hur SM, Kim SY, et al. Pegfilgrastim for primary prophylaxis of febrile neutropenia in breast cancer patients undergoing TAC chemotherapy. Ann Surg Treat Res. 2018;94(8):223-8.

16. Rajan SS, Stearns CS, Lyman HG, Carpenter RW. Effect of primary prophylactic G-CSF use on systemic therapy administration for elderly breast cancer patients. Breast Cancer Res Treat. 2011;130(1):255-66.

17. Crawford J, Glaspy JA, Stoller RG, Tomita DK, Vincent ME, Mcguire BW, et al. Final Results of a Placebo-Controlled Study of Filgrastim in SmallCell Lung Cancer: Exploration of Risk Factors for Febrile Neutropenia. Support Cancer Ther. 2005;3(1):36-46.

18. Scott SD, Chrischilles EA, Link BK, Delgado DJ, Fridman M, Stolshek BS. Days of Prophylactic Filgrastim Use to Reduce Febrile Neutropenia in Patients With Non-Hodgkin's Lymphoma Treated With Chemotherapy. J Manag Care Pharm. 2003;9(2):15-21.

19. Chan A, Chen C, Chiang J, Tan SH, Ng R. Incidence of febrile neutropenia among early-stage breast cancer patients receiving anthracyclinebased chemotherapy. Support Care Cancer. 2012;20(7):1525-32.
20. Pettengell R, Szucs TD, Jackisch C, Leonard R, Paridaens R, Constenla M. Multivariate analysis of febrile neutropenia occurrence in patients with non-Hodgkin lymphoma: data from the INC-EU Prospective Observational European Neutropenia Study. Br J Haematol. 2009;144(5):677-85.

21. Moreau M, Klastersky J, Schwarzbold A, Muanza F, Georgala A, Aoun M, et al. A general chemotherapy myelotoxicity score to predict febrile neutropenia in hematological malignancies. Ann Oncol. 2009;20(3):513-9.

22. Lyman GH, Delgado DJ. Risk and Timing of Hospitalization for Febrile Neutropenia in Patients Receiving CHOP, CHOP-R, or CNOP Chemotherapy for Intermediate-Grade NonHodgkin Lymphoma. Cancer. 2003;98(11):24029.

23. Arai Y, Kanda E, Iimori S, Naito S, Noda Y, Sasaki S, Sohara E, Okado T, Rai T, Uchida S. Low white blood cell count is independently associated with chronic kidney disease progression in the elderly : the CKD-ROUTE study. Clin Exp Nephrol. 2018;22(2):291-8.

24. Hosmer W, Malin J, Wong M. Development and validation of a prediction model for the risk of developing febrile neutropenia in the first cycle of chemotherapy among elderly patients with breast, lung, colorectal, and prostate cancer. Support Care Cancer. 2011;19(3):333-41.

25. Fontanella C, Bolzonello S, Lederer B, Aprile G. Management of Breast Cancer Patients with Chemotherapy-Induced Neutropenia or Febrile. Breast Care. 2014;9(4):239-45.

26. Kuderer NM, Dale DC, Crawford J, Lyman GH. Impact of primary prophylaxis with granulocyte colony-stimulating factor on febrile neutropenia and mortality in adult cancer patients receiving chemotherapy: a systematic review. InDatabase of Abstracts of Reviews of Effects (DARE): Quality-assessed Reviews [Internet] 2007. Centre for Reviews and Dissemination (UK). 